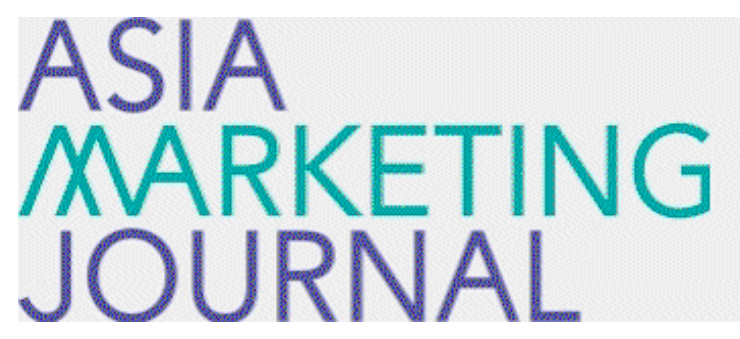

ASIA MARKETING JOURNAL

Volume 10 | Issue 4

Article 2

1-30-2009

\title{
가치구조와 환경소비주의에 관한 타 문화간 비교연구
}

\section{Yeon Shin Kim}

Se Jung Marina Choi

Nora Rifon

Follow this and additional works at: https://amj.kma.re.kr/journal

Part of the Marketing Commons

\section{Recommended Citation}

Kim, Yeon Shin; Choi, Se Jung Marina; and Rifon, Nora (2009) "가치구조와 환경소비주의에 관한 타 문화간 비교연 구," Asia Marketing Journal: Vol. 10 : Iss. 4 , Article 2.

Available at: https://doi.org/10.53728/2765-6500.1226

This Article is brought to you for free and open access by Asia Marketing Journal. It has been accepted for inclusion in Asia Marketing Journal by an authorized editor of Asia Marketing Journal. 


\title{
A Cross-Cultural Study of Value Structure and Environmental Consumerism: The Case of Korean and United States Consumers
}

\author{
가치구조와 환경소비주의에 관한 타 문화간 비교연구: \\ 한국과 미국 소비자사례
}

Kim, Yeonshin(김 연 신)*

Choi, Sejung Marina(최 세 정)**

Nora Rifon(노라 리폰)***

In an effort to increase our understanding of green buying behavior, the present study proposes and tests a comprehensive model of how values influence attitudes toward the environment and preferences for green products in a cross-cultural setting. Data were collected from a survey with consumers in two cultures, diametrically different on values salient to environmental consumerism, the U.S. and Korea. As a result of model testing both at the national and multi-group levels, a refined, final model is presented. While the core human values were found to relate to environmental attitudes and green buying behavior, the patterns of the relationships among the variables emerged to differ between the two cultures, highlighting the importance of cross-cultural investigations in this area. Results suggest that biospheric values significantly influence environmental attitudes and green consumption in both countries. However, the effects of egoism were significant among American respondents whereas altruism appeared to have a significant influence on attitude and behavior in the Korean sample. Findings of this study should aid international marketers in their understanding of what drives consumers' green buying behavior in different cultural settings.

Key words: Value Structure, Environmental Attitudes, Green Purchase Behavior, Cross-Cultural Study

* Department of Business Administration, Myongji University (yeonshin67@mju.ac.kr)

** Department of Advertising. The University of Texas at Austin(marina@mail.utexas.edu)

*** Department of Advertising, Michigan State University(rifon@mail.msu.edu) 


\section{Introduction}

Environmental protection issues are at the forefront of the international business agenda. Four decades have passed since the inception of Earth Day and the burgeoning acceptance of being "green." During that period, environmental consumerism (i.e., buying and consuming products that are benign toward the environment) has received worldwide attention as more consumers around the world become aware of a product's impact on the environment (Dagnoli 1991: Marketing News 1997: Morris et al. 1995; Park and Kim 2003: Beï̈ng Review 2002) and more environmentally considered products become available in the global marketplace (Bryner and Alex 2006: Goldstein 1996: Klein 1990; Kohl 1990: Lawrence 1993). The mounting concern for the environment is manifested in the substantial number of consumers around the world who incorporate information about the environmental impact of product manufacturing, usage and disposal into brand evaluations (Cramer 1991: Carlson et al. 1993: Hastak et al. 1994; Kelly 1993; Levin 1990: Ottman 1998: Selling 2002: William 2000)

Notwithstanding what appears to be a continued, growing concern for and positive attitude toward the environmental protection, there is little evidence that consumers translate that concern into consumption related behaviors (Fowler 2002: Mayer et al. 1993: Schwartz and Miller 1991: Shrum et al. 1995). For instance, only 14 to 30 percent (varying with product categories) of American consumers surveyed in urban, middle-class communities reported having purchased a product because of its positive environmental impact although they expressed a strong environmental concern (Mainieri et al. 1997). This inconsistency between consumer ecological concern and actual behavior hinders the prediction and understanding of the purchase of environmentally responsible products despite the growing intention to encourage green behavior among marketers and policymakers.

Some argue that the modest academic understanding of the antecedents of pro-environmental behavior can be ascribed to past research characterized by a strong focus on the single variable, environmental attitudes and inattention to the far-reaching, underlying motivational structure that may drive environmental concern and behavior (Grunert-Beckmann and Kilbourne 1997; Kilbourne et al. 1997: Stern et al. 1995). Previous research in several countries such as the U.S. (McCarty and Shrum 1994), Canada (Follows and Jobber 2000), and China (Chan 2001) jointly points to the importance of personal values in predicting ecological behavior. Therefore, as an antecedent of environmental behavior, personal values should be included in advanced environmental studies. In addition, much early environmental research presumed environmental behavior to be a unitary, undifferentiated category. Yet, recently the needs of studying independently

\section{6 한국마케팅저널 제10권 제4호 2009년 1월}


a particular type of environmental behavior have been strongly suggested because proenvironmental behaviors can be classified into several distinct types and different combinations of causal factors determine the different types better. Thus, given the increased interest in environmental protection when making purchase decisions, it is essential to comprehend green buying behavior and what motivates such behavior. Little research has addressed the nature of the links among these key variables, values, attitudes and ecological purchase behavior, in a comprehensive framework.

The study presented in this paper, therefore, attempts to narrow the gap in our understanding of green buying behavior by widening the range of variables examined and focusing on how the structure and depth of basic human values relate to ecological attitudes and consumption behavior in an integrative manner. Addressing another limitation of the research on environmental issues, its lack of universality (Schultz and Zelezny 1998), the present study tests a model of how values influence attitudes toward the environment and preferences for green products in a cross-national setting. Most previous research has focused on the U.S. and Western cultures, thereby limiting our understanding of the influence of environmental concern and related values on subsequent purchase behaviors in other cultures. A review of cross-national research on environmental issues (e.g., Dunlap et al. 1993) suggests that the varying degree of environmental concern across countries is not explained by the country's economic wealth. Instead, culture appears to be the key factor in driving differences in environmental attitudes across countries (Chavez 1984; Lynch 1993), highlighting the imperative need to test a model of ecological consumption behavior in different cultural contexts.

Therefore, two countries that are diametrically different on their cultural values salient to environmental consumerism: the U.S. and Korea have been selected for model testing in this study. While the two countries selected differ in their fundamental value orientations, there appeared to be little difference in their overall level of environmental concern and behavioral efforts. Government reports (Government Information Agency 2003: Seoul City 1997) indicated that a majority of Koreans shared a concern over environmental problems and had previously engaged in one or more of environmentally conscious behaviors. Theoretically, this study proposes and tests a model integrating values and attitudes for explaining ecological behavior in two different cultural contexts. The results of this study should serve as a starting point for systematic cross-cultural research on the role of values and attitudes in determining ecological consumption related behavior. In managerial terms, the findings from this crosscultural study should aid international marketers in their understanding of what drives consumers' green buying behavior in different cultural 
settings.

\section{Literature Review}

\subsection{Values and Environmentalism: The Role of Personal Values}

The nature of green buying behavior and its underlying motivations are notably different from general consumer behavior (McCarty and Shrum 2001). Engaging in a general purchase behavior is driven by an assessment of its benefits relative to its costs experienced by the individual who performs the behavior. On the other hand, the purchase of an environmentally friendly product is unlikely to directly and immediately benefit the individual consumer despite the premium price so often paid. The outcomes of the green buying behavior in general are future-oriented (e.g., a cleaner environment) and consumers tend to perform pro-environmental behavior for the sake of others rather than themselves (Guagnano et al. 1995; Hopper and Nielsen 1991). For this reason, pro-environmental behavior may be influenced by personal values that transcend self-interest and a deeper understanding of ecological consumption behavior could be gained when such behavior is studied as a function of underlying values (e.g., Rozak 1992).

For decades, environmental consumerism researchers have examined the influence of individual, psychological factors on environmental attitudes and behaviors. Previous research has attempted to identify the underlying values that provide a basis for environmental attitudes as personal values have been found to distinguish more active from less active participants in environmental protection behaviors (Granzin and Olsen 1991). Values, as conceptualized in the tradition of social psychology, are the guiding foundations for attitude development, and consequently, are considered causal deteminants of behavior (Parsons and Shils 1951). Values are distinct from attitudes or beliefs because they function as an organized system and are typically viewed as determinants of attitudes and behaviors (Olson and Zanna 1993). Values are also considered to be more stable and abstract than attitudes and act as standards upon which a large number of attitudes are based. In theory, values can directly motivate and influence behavior (Williams 1979); however, because values are the most abstract form of cognition, the influence of values on behavior may be better understood by concurrently examining more specific attitudes as a mediator.

\subsection{Schwartz's Value Structure and Content}

Schwartz (1992) developed a more sophisticated approach to understanding the complex value structures and identified ten motivationally 
distinct types of values. The ten value types are organized in four higher order value domains that form two basic bipolar dimensions: (1) self-transcendence versus self-enhancement and (2) openness to change versus conservation. These two dimensions constitute the most fundamental aspect of the value system. The structure and content of Schwartz's value system have received strong empirical support in studies with more than 25,000 respondents from 44 countries (Schwartz 1992).

Self-transcendence is associated with benevolence and universalism (motivation to promote the welfare of others and nature), while selfenhancement values are represented by $\mathrm{ac}^{-}$ hievement and power (indicating the extent to which a person is motivated by self-interest). Openness to change is characterized by selfdirection and stimulation (indicating the extent to which a person is motivated to pursue innovative ways), and conservation is linked with conformity, security, and tradition (indicating the extent to which a person is motivated to preserve the status quo). The openness to change and conservation values are orthogonal to the self-enhancement and self-transcendence values (Maio and Olson 1995).

Schwartz's model can be used to predict a general pattern of value-attitude-behavior relations. The self-transoendence/self-enhancement value dimension is particularly salient to the environmental consumerism context. Conceptually, individuals with values that lean toward the self-transcendence pole would be expected to possess pro-environmental protection attitudes and display related behaviors. In contrast, individuals that lean toward the self-enhancement end of the value continuum are likely to experience attitudes and behaviors that prioritize beliefs and outcomes salient to individual goals and disregard their environmental consequences. While empirical findings support these suppositions, the value dimension of openness to change/ conservation appears to have no significant influence on consumer attitudinal or behavioral predispositions towards the environment (Follows and Jobber 2000: Karp 1996: Schultz and Zelezny 1998: Stern et al. 1995).

\subsection{Altruism, Egoism, and Biospheric Values}

Complementing Schwartz value typology is a value-based theory of environmental concern developed by Stern and Dietz (1994). The theory posits that environmental attitudes are the result of a person's more general set of values and proposes three distinct values: the self, all people, and all living things. These three value orientations are respectively labeled egoism, altruism, and biospherism. Individuals with strong egoistic values, associated with self priorities, tend to engage in environmental protection if it helps them personally. Conversely, they oppose environmental protection if the personal costs (sacrifices) are perceived as 
high. Altruistic values, the value orientation toward general human welfare, predispose people toward the environment because environmental damage can have negative consequences for others. Biospherism refers to the value orientation toward the natural environment and disposes people toward its protection for the general ecology of non-human species as well as human beings that co-exist in the biosphere. Individuals who value altruism or biospherism are less likely to value egoism.

Schwartz's and Stern and Dietz's value typologies can be integrated to create a more comprehensive model of the roles that values play in environmental consumerism. Altruism and biospherism are subsets, or more specific types of values that are self-transcendent. Egoism is essentially the same as self-enhancement. Values are widely accepted as the foundations for attitudes and behaviors, but the relationships among the three social-psychological constructs have not been cross-culturally developed within an environmental consumerism context. A unified theory of environmental consumerism integrates these two general value typologies then explicates their relations to cross-cultural environmental consumerism outcomes.

\subsection{Cultural Influences on Values and Environmentalism}

To date, there have been very few crosscultural studies of the links among values and environmentalism indicators. The cross-cultural evidence currently available, although it is rare, indicates that cultural differences may cause differential underlying bases for environmental attitudes and behaviors (e.g., Schultz and Zelezny 1999). Culture, rather than economy. plays a more important role in determining environmental attitudes. Hofstede (1991) defines culture as "the collective mental programming of the people in an environment." Culture is people's way of life (Parker and McDonough 1999), and people within a culture think and act in common ways. Belonging to a culture also means that individuals share similar values because beliefs and values are a critical part of culture. Thus, priorities of values vary from culture to culture (e.g., Grunert et al. 1989). One of the most frequently used cultural orientations in cross-cultural research is individualism versus collectivism. In contrast to individualism, collectivism refers to the extent to which the needs and goals of the collectivity are regarded more highly than those of individuals. According to Hofstede's work (1980), Korea and the U.S. represent two diametrically different cultures along the key cultural dimension of individualism versus collectivism. Korea is characterized as a collectivistic culture, while the U.S. represents a highly individualistic culture. The difference between collectivism and individualism may have a meaningful application to value priorities. For instance, collectivist cultures are thought to put much greater emphasis on values associated

\section{0 한국마케팅저널 제10권 제4호 2009년 1월}


with collective interests than on those with individual interests. But collectivist cultures are relatively indifferent to the needs of outsiders (Triandis 1990: Triandis et al. 1990) because they emphasize values that promote the welfare of their in-group. Korean society cares about group goals but distinguishes between in-group and out-group. By contrast, American society values personal achievement and individual self-worth more than group goals (Furnham 1984: Wayne 1989) and may not have a sharp distinction between in-group and out-group.

Furthermore, the U.S. and Korea substantially differ in their religious heritage, which may affect their views of the environment. With its long history of Buddhism and the influence of Confucianism, Korean culture also emphasizes harmony with nature (Dollinger 1988: Lee 1990). That is, it dictates that people should behave according to the way of nature. However, individuals in American society place a greater emphasis on mastery over nature with the strong influence of Judeo-Christianism. Thus, this cultural contrast between Korea and the U.S. may lead to variations in personal values that consumer attitudes toward the environment and decisions regarding environmental practices are based on (Stern and Dietz 1994).

In summary, given a worldwide concern about the quality of the environment, consumers' pro-environmental consumption has become one of the top interests of marketing managers around the globe. Disappointedly, consumers have not been so active in responding to green products in marketplace (Fowler 2002: Goldman 1991). To provide marketers with helps in developing effective marketing communication programs, it was suggested to investigate the underlying motivations of green purchase behavior. In response to this call for research, the present study examines a theoretical model of ecological consumption in two nations. A cross-cultural test with Korean and American consumers is expected to provide the applicability of the proposed model to international markets with different cultures and broaden the theoretical applications in this area. The following section discusses the development of the model that specifies the relationships among the key variables: values, attitudes, and behavior.

\section{The Model and Hypotheses}

\subsection{Value Structure and General Propositions}

The theory presented here axiomatically uses the integrated value typology as the foundation that drives the salience of attitudinal beliefs, their evaluations, and subsequent behaviors. As such, environmental attitudes are based on the three types of values according to the emphasis that people place on themselves, other people, or plants and animals. In turn, the attitudes 
predispose environmental behaviors. In line with the general pattern of the relations between values found in Schwartz's theory (1992), altruism and biospherism may be positively related to attitudes toward the environment and preferences for green products, while egoism exerts a negative influence on environmental attitudes and predisposition for environmentally friendly products.

\subsection{Personal Values and Environmental Attitudes}

Previous studies indicate a positive relationship between an individual's self-transcendence values and support for environmental protection (Dunlap et al. 1983: Follows and Jobber 2000: Neuman 1986: Rankin 1983; Stern et al. 1995). More specifically, Stern et al. (1993) proposed that environmentally relevant behaviors stem from three distinct value bases: for the welfare of others (altruism), for self (egoism), and for all living things (biospherism) and that each of the three value-based sets of environmental concerns affect environmental behavior. Further, the direction of the relationship between the value types and environmental consciousness could be anticipated with the helps of the Schwartz's value theory. Schultz and Zelezny's (1998, 1999) multinational studies found a significant, positive relationship among the biospheric values, environmental attitudes and pro-environmental behavior in several countries ranging from the U.S. to Latin American and European countries. However, the findings of their studies also provided empirical evidence dictating a negative relationship between egoism and the subsequent commitments to the environment.

It is, thus, expected that individuals who show stronger self-transcendence values than self-enhancement values would express a stronger concern about the environment. Specifically, biospherism, the value for preserving the natural environment, was found to be positively linked to environmental protection attitudes and behaviors, whereas egoism in pursuit of the importance of living a prosperous, comfortable life was negatively related to environmental protection activities (Dunlap et al. 1983: Rankin 1983). Taken together, the findings of prior research and the value-based theoretical framework (Schwartz 1992, 1994: Stern and Dietz 1994) suggest that individuals with altruistic as well as biospheric value orientations of the selftranscendence domain are likely to display stronger pro-environmental attitudes. People with egoistic value orientations are unconcerned or at least apathetic. That is, a strong underlying concern for the welfare of others and for all living things would lead to a higher level of environmental attitudes, whereas a strong desire for enhancing self-interest would be negatively related to attitudes toward the environment. Therefore, the following set of hypotheses delves into the relationship between each of the value types and environmental

\section{2 한국마케팅저널 제 10 권 제4호 2009년 1월}


attitudes.

H1a: Consumer altruistic values are positively related to attitudes toward the environment.

H1b: Consumer biospheric values are positively related to attitudes toward the environment.

H1c: Consumer egoistic values are negatively related to attitudes toward the environment.

\subsection{Values and Green Buying Behavior}

Values have also been shown to exert a direct influence on pro-environmental behavior (e.g., Karp 1996: Schultz and Zelezny 1998). For example, self-transcendent values are stronger among people who engage in pro-environmental activities (e.g., Stern and Dietz 1994: Stern et al. 1995). Thus, the ways values affect green buying behavior are assumed to be similar to the pattern for environmental attitudes. That is, biospheric and altruistic values are supposed to have a positive relationship with green buying behavior, while egoistic values are posited to be negatively related to ecological buying behavior.

H2a: Consumer altruistic values are positively related to green buying behavior.

H2b: Consumer biospheric values are positively related to green buying behavior.

H2c: Consumer egoistic values are negatively related to green buying behavior.
3.4 Attitude and Green Buying Behavior

Perhaps the predominant variable used to explain environmentally conscious behavior is attitude toward the environment or environmental concerns (Hines et al. 1987). An individual's environmental concern level appears to be related to various types of environmental behaviors such as purchase of green products (Chan 1996: Donaton and Fitzgerald 1992: Kerr 1990: Ottman 1993: Schlossberg 1992), recycling (Kellgren and Wood 1986: Simmons and Widmar 1990), and energy saving (Neuman 1986). Consumers with favorable attitudes toward the environment would be more motivated to buy environmentally considered products because they consider more importantly the ecological dimension of the product when making a purchase decision (Kinnear and Taylor 1973). Products perceived as having environmentally sound attributes are more likely to be purchased by environmentally conoerned consumers. Therefore. the following hypothesis is proposed to examine the relationship between attitudes toward the environment and green buying behavior.

\section{H3: Attitudes toward the environment is positively related to green buying behavior.}

Hypotheses 1 through 3 describe a pattern of bivariate causal relationships that jointly provide a model of how values provide the foundation for environmentally concerned attitudes and 
subsequent purchase toward environmentally considered products. Bringing the aforementioned lines of research, in this model, values are posited to influence green buying behavior both directly and indirectly via environmental attitudes. Previous studies focused on the impact of either values or environmental concern/ attitude on pro-environmental behavior, but the fragmented literature does not provide insight to the sequential path of the influences among the three variables, which flows from values to environmental attitude and subsequently to green buying behavior. As values are guiding principles and formed at the fundamental level, they are assumed to influence environmentconscious purchase through attitude that is more specific to the behavior as well as exert a direct influence. Therefore, both direct and indirect influences of values on green purchase behavior and the mediating role of environmental attitude are assessed in the proposed model. The proposed model is displayed in Figure 1.

While some of the proposed relationships have been shown to exist in the U.S. literature,

〈Figure 1〉 Proposed Model

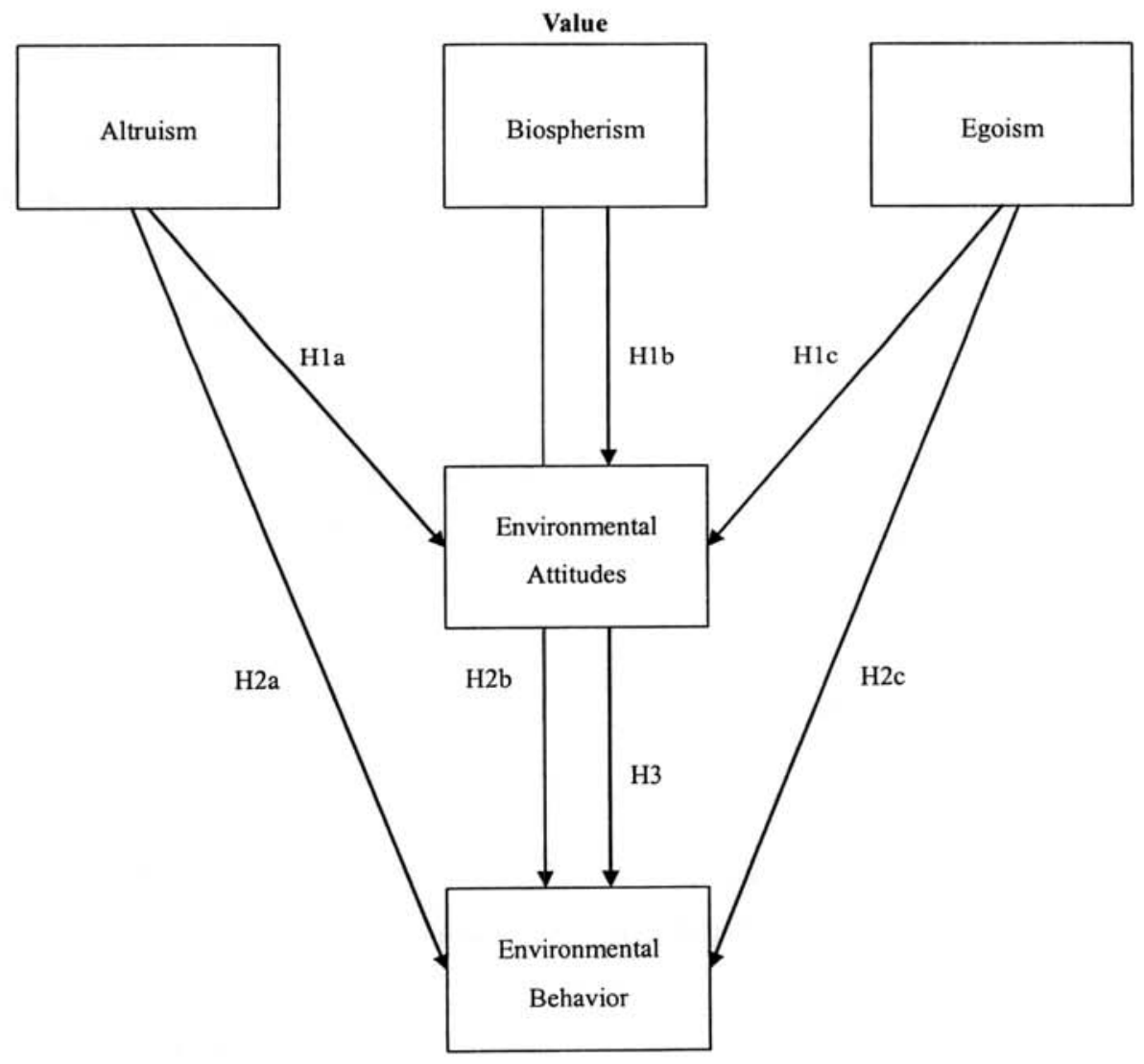


a comprehensive model with all the expected relationships among the key variables has not been tested in previous American studies or cross-culturally. As fundamental values tend to diverge from culture to culture (De Mooij 1998, 2003), the relationships among the constructs in the proposed model might not be uniformly applied in different cultures. Accordingly, a cross-cultural investigation of the model is needed to test its applicability across cultures and advance our understanding of green buying behavior around the world.

\section{Method}

\subsection{Participants}

A total of 531 undergraduate college students in the United States $(\mathrm{N}=289)$ and Korea $(\mathrm{N}=242)$ participated in this study. For comparability of the samples between the two countries, respondents were selected in terms of similarity in their demographic characteristics as well as the location of school and residence. The U.S. sample was drawn from undergraduates enrolled at a major Midwestern university, and the Korean sample consisted of college students registered at a university in a major city, Korea. It could be argued that the use of a nonprobability, student sample could limit the value of the study's findings. However, student samples have value in this context for two reasons. First, they represent the future of environmentalism. Second, one main purpose of the study was to examine relationships among psychological correlates of behavior, and not necessarily to generalize the values associated with each variable to the greater population. As such, a student sample is an economical first step to test if the relationships posed warrant further investigation. For the U.S. group, the respondents' age ranged from 18 years to 29 years, with a mean age of 21 years. Forty percent of the U.S. respondents were male, $60 \%$ were female. Ethnically, $82.3 \%$ were Caucasian and $17.7 \%$ fell in other categories (11.7\% for Black, $2 \%$ for Asian/Pacific Islander, $1.3 \%$ for Chicano/Hispanic, and 2.7\% for others). For the Korean sample, ages ranged between 18 and 29, with an average of 22 years. Forty percent of the Korean participants were male and $60 \%$ were female. The majority of both Korean (76\%) and American (72\%) respondents majored in advertising, communications, or telecommunications. Both the U.S. and Korea samples were relatively homogeneous and comparable in terms of key demographic characteristics.

\subsection{Measures}

The data for this study were collected through a self-administered survey. The questionnaire was originally constructed in English and then translated into Korean by native Korean 
speakers who were also fluent in English. The questionnaire was again back-translated to English to ensure comparability.

The questionnaire consisted of three main sections. The first part of the survey contained self-reported measures of green buying behavior. Respondents were asked to rate how often they had performed a series of ecological consumption related behaviors on a five-item, five-point scale ranging from "never" to "always" (e.g., McKenzie-Mohr et al. 1995: Roberts 1996). Using the New Environmental Paradigm (NEP) scale that has been widely used to measure environmental attitudes in previous studies (Dunlap and Van Liere 1978: Noe and Snow 1989-1990) the second section of the questionnaire assessed respondents' attitudes toward the environment on a seven-item, seven-point Likert-type scale with the end points labeled "strongly agree" and "strongly disagree."

In the third part of the survey, the three types of values - altruism, biospherism, and egoism - were measured with a set of items borrowed from Schwartz's Value Survey (1992, 1994): the egoistic orientation was assessed with value items for self-enhancement, the altruistic value was gauged with self-transcendenœe items specific to welfare of other people, and the biospherism was measured with selftranscendence items related to the natural environment encompassing people (Stern et al. 1995). Respondents rated the importance of each of the value statements "as a guiding principle" in their life on a seven-point scale ranging from "not important at all" to "extremely important." At the end of the questionnaire, information on demographic characteristics including gender, age, race, major, and the type of residence was obtained. Table 2 presents the items measured for the key constructs.

\section{Analysis and Results}

\subsection{Overview}

To understand interrelationships among the constructs of interest, the proposed model was tested and retested with AMOS 4, using the two-step model-building approach that tests the measurement model before examining the hypothesized structural linkages (Anderson and Gerbing 1988). In the first stage, a measurement model that included latent constructs and indicators was analyzed. As the next step, the proposed model with hypothesized relationships was tested and refined through a series of tests in an attempt to better explain the data. A final, modified model for each country is presented as a result.

Following the approaches suggested in the cross-cultural psychology literature (Hui and Triandis 1985: Irvine and Carroll 1980), the equivalence of the measures and the relation- 
ships among the constructs were first examined both at a national level and a multi-group level. While the cultural-level analysis testes the measures and the hypothesized relationships among constructs in each country separately, the multi-group analysis examines the overall pattern of the measurement and the structural relationships across countries. These analyses together offer a more rigorous test of the applicability of the model in cross-cultural settings.

\subsection{Assessment of the Measurement Model}

Confirmatory factor analysis was performed to test a measurement model with the Korean and the U.S. samples respectively in the first step. To assess relationships among constructs and determine applicability of a model in cross-cultural settings, full or partial metric invariance must be satisfied (Berry 1980: Steenkamp and Baumgartner 1998). Metric equivalence in cross-cultural research is established when the properties of measures (i.e., measure dimensionality and internal consistency) display a similar pattem across cultures (Durvasula et al. 1993).

Since the factor structure of the value constructs was of particular interest, the discriminant validity and dimensionality of the altruistic, biospheric, and egoistic values were first evaluated with the two country samples

$\langle$ Table 1〉 Comparisons of the Value Factor Structure by Country

\begin{tabular}{lcc}
\hline & US & Korea \\
\hline Dimensionality and discriminant validity: & & \\
Chi-square of the one-factor model (20 df) & 243.97 & 176.37 \\
Chi-square of the two-factor model 1 (19 df) & 156.10 & 53.88 \\
Chi-square of the two-factor model 2 (19 df) & 129.44 & 170.37 \\
Chi-square of the two-factor model 3 (19 df) & 123.67 & 173.22 \\
Chi-square of the three-factor model (17 df) & 36.37 & 46.99 \\
\hline
\end{tabular}

Fit indices for the three-factor model

$\begin{array}{lll}\text { GFI } & .97 & .96 \\ \text { AGFI } & .94 & .91 \\ \text { CFI } & .96 & .93 \\ \text { RMSEA } & .06 & .09 \\ \text { RMR } & .07 & .10\end{array}$

Note: All of the chi-square values are significant at the .01 level. When the degree of freedom (d.f.) is 2, a chi-square difference value of 5.99 represents a significant difference at the .05 level, and a chi-square difference of 9.21 denotes a significant difference at the .01 level. With the 3 d.f., a chi-square difference value of 7.81 represents a significant difference whereas 11.34 represents a significant difference at the .01 level. 


\begin{tabular}{|c|c|c|c|c|c|}
\hline \multirow[b]{2}{*}{ Factors } & \multirow[b]{2}{*}{ Indicators } & \multicolumn{2}{|c|}{ U.S. } & \multicolumn{2}{|c|}{ Korea } \\
\hline & & Unstd. & Std. & Unstd. & Std. \\
\hline \multirow[t]{3}{*}{ Altruism } & Loyal & 1.00 & .48 & 1.00 & .41 \\
\hline & Helpful & 2.11 & .70 & 1.68 & .79 \\
\hline & Honest & 1.86 & .80 & 1.48 & .71 \\
\hline \multirow[t]{3}{*}{ Egoism } & Social Power & 1.00 & .61 & 1.00 & .72 \\
\hline & Authority & 1.03 & .74 & 1.15 & .70 \\
\hline & Wealth & .48 & .39 & .79 & .58 \\
\hline \multirow[t]{2}{*}{ Biospherism } & Protecting the environment & 1.00 & .93 & 1.00 & .57 \\
\hline & Unity with nature & .83 & .75 & .95 & .72 \\
\hline \multirow[t]{7}{*}{$\begin{array}{l}\text { Environmental } \\
\text { Attitudes }\end{array}$} & $\begin{array}{l}\text { We are approaching the limit of the number of people the } \\
\text { Earth can support. }\end{array}$ & 1.00 & .59 & 1.00 & .58 \\
\hline & Mankind is severely abusing the environment. & 1.08 & .69 & .82 & .44 \\
\hline & The balance of nature is very delicate and easily upset. & 1.09 & .76 & 1.34 & .67 \\
\hline & $\begin{array}{l}\text { The Earth is like a spaceship, with only limited room and } \\
\text { resources. }\end{array}$ & .87 & .55 & .82 & .34 \\
\hline & $\begin{array}{l}\text { Humans must live in harmony with nature in order to } \\
\text { survive. }\end{array}$ & .86 & .62 & .69 & .46 \\
\hline & $\begin{array}{l}\text { To maintain a healthy economy we will have to develop a } \\
\text { "steady-state economy where industrial growth is controlled. }\end{array}$ & .71 & .50 & .62 & .35 \\
\hline & $\begin{array}{l}\text { When humans interfere with nature it often produces } \\
\text { disastrous consequences. }\end{array}$ & 1.20 & .75 & 1.00 & .68 \\
\hline \multirow[t]{5}{*}{$\begin{array}{l}\text { Green Buying } \\
\text { Behaviors }\end{array}$} & $\begin{array}{l}\text { When I have a choice between two equal products, I } \\
\text { purchase the one less harmful to other people and the } \\
\text { environment. }\end{array}$ & 1.00 & .67 & 1.00 & .53 \\
\hline & I have switched products for ecological reasons. & 1.01 & .78 & 1.29 & .68 \\
\hline & $\begin{array}{l}\text { I have avoided buying a product because it had potentially } \\
\text { harmful environmental effects. }\end{array}$ & .93 & .68 & 1.12 & .57 \\
\hline & $\begin{array}{l}\text { I make a special effort to buy paper (e.g., toilet paper, } \\
\text { Kleenex, paper towel) that plastic products that are } \\
\text { made from recycled materials. }\end{array}$ & .82 & .65 & .76 & .48 \\
\hline & $\begin{array}{l}\text { I make a special effort to buy household chemicals such as } \\
\text { detergents and cleansing solutions that are environmentally } \\
\text { friendly. }\end{array}$ & 1.02 & .76 & 1.20 & .70 \\
\hline
\end{tabular}

Note: All factor loadings are significant $(\mathrm{p}<.001)$. "Unstd." and "Std." represent unstandardized and standardized coefficients respectively.

Goodness of fit statistics

U.S. $x^{2}=313.53$ (d.f. $=160$ ), $\mathrm{p}<.001$, GFI $=.90$, AGFI $=.87$, CFI $=.91$, RMSEA $=.06$, RMR $=.08$

Korea: $x^{2}=306.32$ (d.f. $=160$ ), $\mathrm{p}<.001$, GFI $=.89$, AGFI $=.86$, CFI $=.86$, RMSEA $=.06$, RMR $=.11$

Multigroup: $x^{2}=619.87$ (d.f. $=320$ ), $\mathrm{p}<.001, \mathrm{GFI}=.90, \mathrm{AGFI}=.86, \mathrm{CFI}=.89$, RMSEA $=.04, \mathrm{RMR}=.09$ 
respectively. A series of confirmatory factor models consisting of one, two, or three factors was estimated on a country-by-country basis. The three-factor-model represented the hypothesized structure in which the three value types were distinct constructs although they were correlated with each other. The three two-factor models tested corresponded to the three possible combinations of the value constructs: (1) altruism and biospherism as one factor and egoism as the other factor, (2) altruism and egoism as one factor and biospherism as the other factor, and (3) biospherism and egoism as one factor and altruism as the other factor. The one-factor model contained only a single construct representing all three-value types together. The chi-square values of the different factor models were compared in each country. As shown in Table 1, the three-factor model was significantly better fitted than any of the two-factor models or the one-factor model in both countries, thereby rendering evidence for discriminant validity of the three value constructs (Bagozzi and Philips 1982).

In the next step, to assess the invariance of the factor structure of the constructs, a confirmatory factor model including all five constructs was compared using multi-group analysis with the U.S. and Korea samples as two groups. First, an unconstrained model, in which all factor loadings and correlations among the latent constructs allowed to vary between the samples, was estimated. Second, a constrained model, with the same loadings and correlations set to be equal between the two samples, was estimated (Bollen 1989: Joreskog and Sorbom 1993). The chi-square value of the unconstrained model value was 619.87 (d.f. $=320$ ) and compared to that of the constrained model that was 636.77 (d.f. $=335$ ). The chi-square difference was not significant $\left(x_{\text {diff }}^{2}=16.91\right.$, d.f. $\left.=15, \mathrm{p}>1\right)$, indicating that the factor structure achieved metric equivalence between the two samples.

All of the items or indicators in the con-

〈Table 3〉 Descriptive Statistics and Scale Reliability Coefficients

\begin{tabular}{lccccccccc}
\hline & & \multicolumn{3}{c}{ U.S. } & \multicolumn{5}{c}{ Korea } \\
\hline \multicolumn{1}{c}{ Construct } & Range & $\mathrm{M}$ & $\mathrm{SD}$ & $\mathrm{a}$ & $\mathrm{AVE}$ & $\mathrm{M}$ & $\mathrm{SD}$ & $\mathrm{a}$ & AVE \\
Altruism & $9-21$ & 18.75 & 2.04 & .67 & .45 & 17.36 & 2.61 & .65 & .43 \\
Biospherism & $2-14$ & 9.98 & 2.45 & .82 & .36 & 10.60 & 2.13 & .58 & .45 \\
Egoism & $6-21$ & 13.79 & 2.86 & .60 & .71 & 15.50 & 2.92 & .70 & .42 \\
Environmental Attitudes & $13-49$ & 35.97 & 6.39 & .83 & .41 & 38.10 & 5.66 & .70 & .27 \\
Green Buying Behavior & $5-24$ & 12.37 & 4.26 & .83 & .50 & 13.04 & 3.54 & .72 & .36 \\
\hline
\end{tabular}

Note: All items were measured on a 7-point scale except for behavior items (5 points). 
firmatory factor model were found to significantly load on the corresponding, hypothesized factors $(\mathrm{p}<.001)$. Table 2 reports the factor loadings (both unstandardized and standardized) for each latent variable and goodness-of-fit indices of the measurement model for both the Korean and U.S. samples. The items explaining each of the five latent constructs were respectively summed to form an index score after being evaluated for internal consistency, which resulted in a total of five indices. The descriptive statistics, reliability coefficients, and average variance extracted (AVE) appear in Table 3 and the correlations among the constructs are reported in Table 4.

\subsection{Test of the Hypotheses}

The hypothesized relationships among constructs in the proposed model were estimated separately for each country. Similar to some previous studies (Fang et al. 2004: Goldsmith et al. 2000: Joreskog and Sorbom 1993), path analysis was performed to test the hypothesized relationships among constructs because many of the error terms of the observed variables were correlated. A single variable measuring each construct was obtained by summing the corresponding scale items.

Results showed similarities and differences between the Korean and American consumers. Using the U.S. sample, four of the seven hypothesized relationships were statistically significant in the expected direction. In support of $\mathrm{H} 1 \mathrm{~b}$ and $\mathrm{H} 2 \mathrm{~b}$, biospheric values were found to have direct, positive effects on environmental attitudes (standardized path coefficient $=.42$, $\mathrm{p}<.01$ ) and green buying behaviors (standardized path coefficient $=.26, \mathrm{p}<.01)$. As predicted, egoistic values had a direct but negative influence on green buying behaviors (standardized path coefficient $=-.12, \mathrm{p}<.05)$, confirming H2c. Attitudes toward environmental issues also appeared to significantly influence pro-environmental behaviors (standardized path coefficient $=.22, \mathrm{p}<.01$ ), lending support for

$\langle$ Table 4$\rangle$ Correlation Matrix

\begin{tabular}{lccccc}
\hline & 1 & 2 & 3 & 4 & 5 \\
\hline 1. Altruism & 1.00 & $.52^{* *}$ & $.21^{* *}$ & $.25^{* *}$ & $.15^{*}$ \\
2. Biospherism & $.30^{* *}$ & 1.00 & .07 & $.28^{* *}$ & $.18^{* *}$ \\
3. Egoism & .06 & .11 & 1.00 & .08 & .08 \\
4. Environmental Attitudes & .11 & $.41^{* *}$ & .00 & 1.00 & $.23^{* *}$ \\
5. Green Buying Behavior & .09 & $.34^{* *}$ & -.09 & $.33^{* *}$ & 1.00 \\
\hline
\end{tabular}

Note: ${ }^{*} \mathrm{p}<.05,{ }^{* *} \mathrm{p}<.01$. Correlations of the U.S. sample are in the lower triangle and those of the Korea sample are in the upper triangle. 
〈Table 5〉 Proposed Model: Parameter Estimates and Summary of Model-Fit Statistics

\begin{tabular}{|c|c|c|c|c|c|c|}
\hline & \multirow{2}{*}{$\begin{array}{l}\text { Relationship } \\
\text { From } \rightarrow \text { To }\end{array}$} & \multicolumn{2}{|c|}{ U.S. } & \multicolumn{2}{|c|}{ Korea } & \multirow[t]{2}{*}{ Multi-group } \\
\hline & & \multirow{2}{*}{$\frac{\text { Unstd. }}{-.05}$} & \multirow{2}{*}{$\begin{array}{r}\text { Std. } \\
-.02\end{array}$} & \multirow{2}{*}{$\begin{array}{c}\text { Unstd. } \\
.29\end{array}$} & \multirow{2}{*}{$\frac{\text { Std. }}{.24^{* *}}$} & \\
\hline $\mathrm{Hla}$ & Altruism $\rightarrow$ Environmental Attitudes & & & & & \\
\hline $\mathrm{H} 1 \mathrm{~b}$ & Biospherism $\rightarrow$ Environmental Attitudes & 1.10 & $.42^{* *}$ & .55 & $.27^{* *}$ & \\
\hline $\mathrm{Hlc}$ & Egoism $\rightarrow$ Environmental Attitudes & .15 & -.04 & .07 & .09 & \\
\hline $\mathrm{H} 2 \mathrm{a}$ & Altruism $\rightarrow$ Behavior & -.01 & -.01 & .05 & .07 & \\
\hline $\mathrm{H} 2 \mathrm{~b}$ & Biospherism $\rightarrow$ Behaviors & .46 & $.26 * *$ & .17 & .04 & \\
\hline $\mathrm{H} 2 \mathrm{c}$ & Egoism $\rightarrow$ Behaviors & -.18 & $-.12^{*}$ & .06 & .05 & \\
\hline $\mathrm{H} 3$ & Environmental Attitudes $\rightarrow$ Behaviors & -.09 & $.22^{* *}$ & .12 & $.24^{* *}$ & \\
\hline \multicolumn{7}{|c|}{ Goodness-of-fit indices } \\
\hline & $x^{2}($ d.f. $)$ & \multicolumn{2}{|c|}{3.64} & \multicolumn{2}{|c|}{11.53} & $15.17(4)^{* *}$ \\
\hline & RMR (Root Mean Square Residual) & \multicolumn{2}{|c|}{.33} & \multicolumn{2}{|c|}{.20} & .79 \\
\hline & Goodness of Fit Index (GFI) & \multicolumn{2}{|c|}{.99} & \multicolumn{2}{|c|}{.98} & .99 \\
\hline & Adjusted GFI (AGFI) & \multicolumn{2}{|c|}{.96} & \multicolumn{2}{|c|}{.86} & .92 \\
\hline & Comparative Fit Index (CFI) & \multicolumn{2}{|c|}{.99} & \multicolumn{2}{|c|}{.92} & .96 \\
\hline & RMSEA & \multicolumn{2}{|c|}{$.05(2)$} & \multicolumn{2}{|c|}{$.14(2)^{* *}$} & .07 \\
\hline
\end{tabular}

Notes: ${ }^{*} \mathrm{p}<.05,{ }^{* *} \mathrm{p}<.01$, All other coefficients are not significant, $\mathrm{p}>.1$.

H3. Contrary to expectations, however, the other proposed causal relationships were not significant $(p>.05)$.

With the Korean sample, three of the relationships were significant; altruism and biospherism appeared to positively influence environmental attitudes (standard path coefficient $=24, \mathrm{p}<.01$ for altruism; standardized path coefficient $=.27, \mathrm{p}<.01$ for biospherism) and environmental attitudes were also found to exert a direct, positive influence on green buying behaviors (standardized path coefficient $=.24, \mathrm{p}<.01)$, confirming $\mathrm{Hla}, \mathrm{Hlb}$ and $\mathrm{H} 3$ respectively. The other hypothesized paths were found to be not significant $(p>.05)$.
Overall, the fit statistics of the model in each country showed that the model accounted for the data well (U.S.: $x^{2}=3.64$, d.f. $=2, p$ > $.1, \mathrm{RMR}=.33, \mathrm{GFI}=.99, \mathrm{AGFI}=.96, \mathrm{CFI}$ $=.99$, RMSEA $=.05:$ Korea: $x^{2}=11.53$, d.f. $=2, \mathrm{p}<.01, \mathrm{RMR}=.20, \mathrm{GFI}=.98$, AGFI $=.86, \mathrm{CFI}=.92$, RMSEA $=.14)$. Path coefficients for the proposed model in each country are reported in Table 5 .

In addition to the national level analysis that assessed the relationships among the constructs applied in each country separately, a more rigorous test of the model using multiple group analysis was performed to assess cross-cultural applicability of the model. The unconstrained 
model $\left(x^{2}=15.17\right.$, d.f. $\left.=4, \mathrm{p}<.1\right)$ and the constrained model $\left(x^{2}=30.08\right.$, d.f. $=11, p<$ .1) were estimated and the chi-square difference between the two models was significant $\left(x^{2}\right.$ diff $=14.92$, d.f. $\left.=7, p<.05\right)$. These results indicated that the structural paths were not fully invariant between the two countries. For this reason, the models were further examined in each country separately.

In an attempt to refine the models and achieve parsimony, the non-significant relationships were tested in each country in the second phase of the analysis by systematically relaxing a restriction and examining the resultant change in chi-square. That is, the chi-square indices of the models without each of the non-significant paths were re-estimated and compared to that of the originally proposed model. For the U.S. sample, the paths (1) from altruism to environmental attitudes (Hla), (2) from egoistic values to attitudes (Hlc), and (3) from altruism to green buying behaviors $(\mathrm{H} 2 \mathrm{a})$ were tested and found to yield non-significant changes in chi-square: (1) $X_{\text {diff }}^{2}$ $=.08$, d.f. $=1, \mathrm{p}>.05:(2) X^{2}$ diff $=.55$, d.f. $=1, p>.05:$ and $(3) x_{\text {diff }}^{2}=.01$, d.f. $=1, p$ $>.05$.

Likewise, the four non-significant relationships from the Korean data were investigated, however no significant chi-square changes were detected for all of the paths (1) from egoistic values to environmental attitudes (Hlc), (2) from altruism to behaviors (H2a), (3) from biospherism to behaviors (H2b), and (4) from egoistic values to behaviors $(\mathrm{H} 2 \mathrm{c})$ : (1) $x_{\text {diff }}^{2}=.35$, d.f. $=1, p>.05:$ (2) $x^{2}$ diff $=.25$, d.f. $=1, p>.05 ;(3) x_{\text {diff }}^{2}=1.87$, d.f. $=1, p$ $>.05$ : and (4) $x_{\text {diff }}^{2}=.57$, d.f. $=1, p>.05$. Hence, these paths, which did not significantly contribute to improvement of the model fit, were removed from the model for each country respectively. In the Korea sample, the altruistic and biospheric values were allowed to covary and the correlation was significant $(.52, \mathrm{p}<$ .001). The final, revised models for both countries with the parameter estimates are presented in Figure 2. The modified models improved in the fit indices compared to the proposed model and accounted for the data very well. The final models are also more parsimonious without any non-significant causal linkages than the originally proposed model.

\section{Discussion}

The goal of this study was to develop a more comprehensive understanding of the predictors of green buying behavior and their interrelationships, within and across cultures. In particular, this study intended to clarify the role that personal values play in guiding environmental consumerism. Cross-cultural study of the value-attitude-behavior model is essential for public policy makers as well as environ- 
US

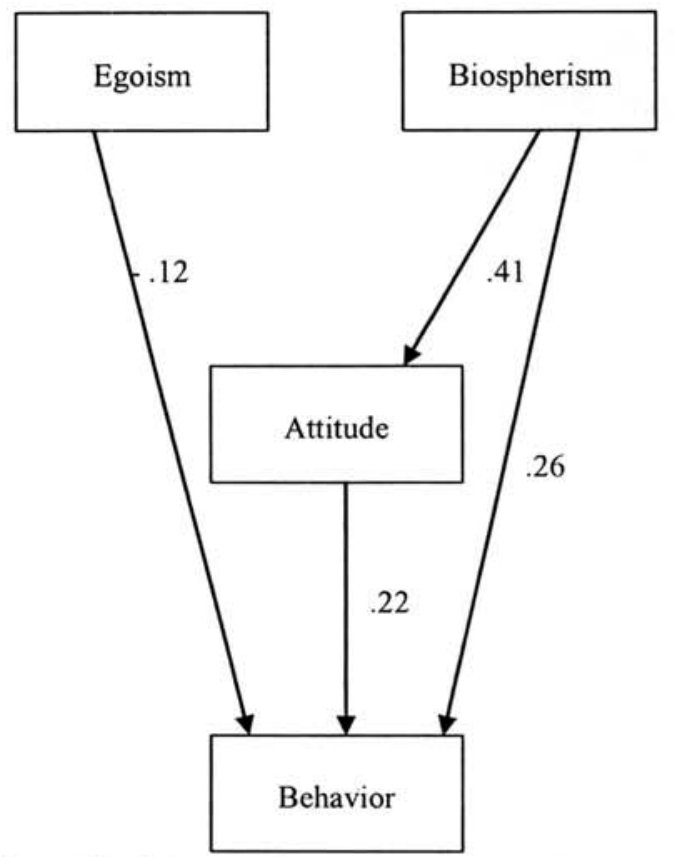

Korea

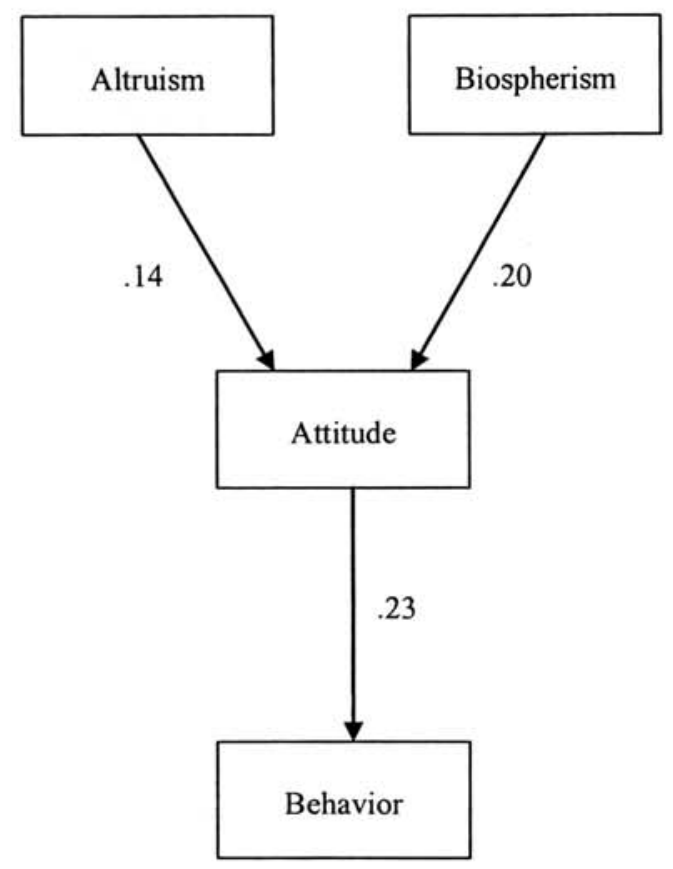

Note: All of the path parameters are standardized coefficients.

Goodness of fit indices

U.S. $: x^{2}=3.92$ (d.f. $=2$ ), $\mathrm{p}>.1, \mathrm{GFI}=.99, \mathrm{AGFI}=.97, \mathrm{CFI}=.98, \mathrm{NFI}=.97, \mathrm{RMSEA}=.06, \mathrm{RMR}=.27$

Korea: $x^{2}=3.99($ d.f. $=2), \mathrm{p}>.1, \mathrm{GFI}=.99, \mathrm{AGFI}=.96, \mathrm{CFI}=.98, \mathrm{NFI}=.97, \mathrm{RMSEA}=.06, \mathrm{RMR}=.10$

mental marketing managers around the world. Marketers and policymakers should be aware of the influence of different cultures and value systems when suggesting programs to promote consumers' pro-environmental choices and consumptions in different cultural settings. To obtain a better understanding of the bases of green buying behavior, the employed theoretical model incorporated relevant value structures from two major sources (Schwartz 1992: Stern et al. 1995). Consistent with past findings, three core human values - altruism, biospherism, and egoism - emerged and demonstrated significant relationships to environmental attitudes and green buying behavior, highlighting their importance in determining environmental consumerism. Notably, a set of biospheric values appeared as a distinct basis of people's support for environmental protection. The values studied should be incorporated into a universal model of ecological consumption to compare and contrast cultural influence on ecological 
attitudes and behaviors. The observed differences between the two countries point to the need for further cross-cultural investigations in this area.

Results on the value structures in the U.S. and Korea suggest that there may be a level of universality to values, but that a fine tuning is necessary to understand the nuances of cultural differences as reflected in values. While the results support the universality of the abstract dimensions, altruism/biospherism/ egoism between the two cultures, the use of specific items representing each value type might need some modifications based on culture. Biospherism was a significant antecedent of environmental attitudes and behaviors in both cultures, but with slightly different paths of influence. The pattern of the relationships among the variables differentiated the two cultures studied with major differences observed for the roles of altruism and egoism.

The model supported by the U.S. data suggests that biospherism, a value for the general ecology of the biosphere, is the most important determinant of environmental attitudes and subsequent behavior. Biospherism values had direct effects on both environmental attitudes and behaviors, as well as an indirect effect on behavior through attitudes. Egoism, the value associated with self-prioritization, was weakly but negatively associated with pro-environmental attitudes, and indirectly with behaviors through its influence on attitudes.
Altruism, the value for others' welfare, did not significantly predict environmental attitudes or behaviors among the American respondents.

The model supported by the data from the Korean sample suggests a different pattern for individuals from a more collectivist culture. Altruism and biospherism significantly and directly influenced pro-environmental attitudes, but had only indirect influence on behaviors through attitudes. Unlike American consumers, egoism had no significant effects on environmental attitude or behavior among the Korean respondents. The differences may have one or more explanations.

It may suggest that the Korean culture sampled here does not consider egoism values to be in concert or conflict with one's predisposition toward the environment. Indeed, one could argue that social power, wealth and authority have no bearing on one's attitude toward the environment. However, individuals from the U.S. experience some inverse relationship indicating that the self may be viewed less as a part of the environment than Koreans who in general consider themselves as an integral part of nature (Lee 1990). It may also be a manifestation of a more individualistic mentality. On the other hand, the model for the more collectivist culture includes the influence of altruism, perhaps reflecting its key cultural value.

Furthermore, it was hypothesized that altruism and biospherism would positively influence environmental attitudes and behaviors as they

\section{4 한국마케팅저널 제10권 제4호 2009년 1월}


represent the higher order value of selftranscendence (which is a measure of the degree to which a person values goals and ideals that are not directly linked to their notion of self). While the direction of the relationship with egoism supports the transcendence/ enhancement continuum for the U.S. sample, the absence of a role for altruism does not. And the lack of an influence of egoism in the Korean sample casts additional doubts. Indeed, the value patterns demonstrated in this crosscultural study might suggest the possibility of cultural impact: that is, while subjects from the U.S. tend to have a narrow definition of self that does not include other people or other living things, Korean subjects tend to have a broader cognitive representation of self including other people or other living things in their notion of self. This difference may affect the relationship between the value typologies and environmental attitudes. In short, these results support the notion that values are linked with environmental attitudes and behavior, but they also suggest the need to reconsider what has established value typologies, in particular for our understanding of environmental consumerism across cultures.

\section{Managerial Implications}

The cross-cultural evidence of this study suggests that perhaps more localized rather than standardized programs would be needed to appeal to consumers who have different commitments to environmental issues for different reasons around the world. It appears that some Korean consumers may view environmental protection not just as an altruistic act (directed to their family and in-group members), but as an act that can protect all living things. With its long heritage of Buddhism and Confucianism, Korean culture regards mankind and nature as existing symbiotically and thereby embracing both of them in the concept of environmental protection. That is, Korean consumers believe that ecologically considered actions can ultimately enhance the entire eco-system including their own welfare. Therefore, it may suggest that for Koreans, self-enhancement as well as selftranscendence values may have a positive impact on ecological consciousness (although in this study egoistic value was not significant enough). However, consistent with the aforementioned religious background, American consumers tend to view nature and humans as separate entities and consider people as consumers or protectors of nature who do not benefit directly from environmental protection (Lynch 1993). That is, the U.S. sample (that is assumed to have a different man-nature orientation from the Korean sample) demonstrates a sharp distinction between self-enhancement and self-transcendence values in terms of environmental consciousness. Also, for them biospherism and altruism that belong 
to a self-transcendent value dimension should not be treated as equally important value types in terms of stimulating consumers' environmentalism, while the two value types are not differentiated for the Korean sample in the relation to environmentalism. In conclusion, the biospheric value orientation (i.e., caring for all living things) shows a strong relationship with proenvironmental attitudes and behavior crossculturally, but egoism and altruism seems to be important specifically to each culture.

Hence, social marketers conoerned with encouraging environmentally responsible behavior in both Korea and the U.S. might target beliefs that environmental responsibility is for the greater good. More specifically, Korean green marketing managers aiming at pro-environmental consumption behavior may achieve their objective by promoting an idea that the consequences of pro-environmental choice are directly related to the welfare of people or healthy plants and animals (both altruistic and biospheric values). Conversely, U.S. consumers might be better influenced by social marketing efforts that emphasize, rather than the self-enhancing outoomes, the self-transcending outcomes associated with pro-environmental behavior. For example, desirable pro-environmental choice among consumers should be promoted by delivering an idea that the choice benefits the earth where all living things survive (biospheric values). Using the results of this study, social marketers and marketers of green products can generate more targeted campaigns on the basis of values that relate to environmental attitudes and purchases. Perhaps the use of green attributes should be revisited in the context of their connections to consumer values. Certainly, further research is necessary to examine these possibilities.

\section{Suggestions for Future Research and Conclusion}

The results of the measurement model test of the value structure in this study suggest that value typologies should be revised in the context of the culture. Schwartz's value measurement scale has been validated in a number of countries, but a further refinement of the scale in cross-cultural settings warrants future studies. While the findings of this study provides empirical evidence of the proposed valueattitude-behavior relationships in the context of ecological consumption, further tests of the model in additional countries and with adult samples are required to enhance our understanding of the roles of biospheric values as well as altruistic and egoistic values in explaining pro-environmental attitudes and various ecological actions across cultures. In doing so, more determinants of ecological behaviors should be identified and incorporated into the modeling. For instance, laws and regulations forcing environmentally friendly behavior in the country 
and an individual consumer's knowledge of the severity and possibility of consequences of environmentally irresponsible behavior may impact the consumer's engagement in proecological behavior. Korean consumers recycle more than their American counterparts, for example, because recycling is legally enforced in Korea whereas recycling is a matter of individuals' choice in the U.S. Another issue that merits further exploration is the assumption of cultural orientations as the explanatory variable of cross-cultural differences. As new communication technologies connect people across the world and expose people to other cultures, consumers' tastes and styles are said to converge on the global scale. Further, the previously well established and applied classification of cultures based on their dominant cultural values might not work any longer because we observe more and more variations in individuals' cultural orientation in a single culture and different cultural values co-exist within a culture (Dutta-Bergman and Wells 2002). Along this line, Korean culture might not be as collectivistic as it used be. A careful investigation of cultural orientations both between and within cultures should provide useful insight to the cross-cultural similarities and differences in this area. The findings of the study indeed point us in that direction.

〈received: 2008. 07. 07〉

〈accepted: 2009. 01. 09〉

\section{References}

Anderson, James C. and David W. Gerbing (1988), "Structural Equation Modeling in Practice: A Revisited and Recommended Two-step Approach," Psychological Bulletin, 103, 411-23.

Bagozzi, Richard P. and L.W. Philips (1982), "Representing and Testing Organizational Theories: A Holistic Construal," Administrative Science Quarterly, 27(3), 459-89.

Beijing Review (2002), "Green Products Market Worth 55 Billion Yuan," 45(50), 25-27.

Berry, John W. (1980), “Introduction to $\mathrm{Me}^{-}$ thodology," in Triandis, H.C. and Berry, J.W. (Eds), The Handbook of CrossCultural Psychology, 2, Allyn \& Bacon, Boston, 1-29.

Bollen, Kenneth A. (1989), Structural Equations with Latent Variables, Wiley: New York. Bryner, Michelle and Scott Alex (2006), “Going Green Ain't Easy: Chemical Firms Gauge Payback," Chemical Week, 168 (135), 2931.

Carlson, Les, Stephen J. Grove and Norman Kangun (1993), “A Content Analysis of Environmental Advertising Claims: A Matrix Method Approach," Journal of Advertising, 22(3), 27-40.

Chan, T. S. (1996), “Concerns for Environmental Issues and Consumer Purchase Preferences: A Two-country Study," Journal of Inter- 
national Consumer Marketing. 9, 43-55.

Chan, Ricky Y.K. (2001), "Determinants of Chinese Consumers' Green Purchase Behavior," Psychology \& Marketing, 18, 389-413.

Chavez, John (1984), The Lost land: The Chicano Image of the Southwest. Albuquerque, NM: University of New Mexico Press.

Cramer, J. (1991), "The Selling of the Green," Time, 138, 48.

Dagnoli, Judann (1991), "Consciously Green," Advertising Age, 61(September), 14.

De Mooij, Marieke (1998), Global Marketing and Advertising: Understanding Cultural Paradoxes, Thousand Oaks, CA: Sage.

De Mooij, Marieke (2003), “Convergence and Divergence in Consumer Behavior: Implications for Global Advertising," International Journal of Advertising, 22(2), 183-202.

Dollinger, Marc J. (1988), “Confucian Ethics and Japanese Management Practice," Journal of Business Ethics, 7, 575-84.

Donaton, Scott, and Kate Fitzgerald (1992), "Polls Show Ecological Concerns is Strong," Advertising Age, 63 (June 15), 49.

Dunlap, Riley E., G. Gallup, and A. Gallup (1993), "Of Global Concern: Results of A Health of the Planet Survey," Environment, 35, 7-39.

Dunlap, Riley E., J. Keith Grieneeks, and Milton Rokeach (1983), "Human Values and Pro-environmental Behavior," in Conn, W.D. (Ed.), Energy and Material Sources:
Attitudes, Values, and Public Policy, Westriew, Boulder, 145-68.

Dunlap, Riley E. and Kent D. Van Liere (1978), "The New Environmental Paradigm," Journal of Environmental Education, 9(4), 10-9.

Durvasula, Srinivas, J. Craig Andrews, Steven Lysonski, and Richard G. Netemeyer (1993), "Assessing the Cross-National Applicability of Consumer Behavior Models: A Model of Attitude toward Advertising in General," Journal of Consumer Research, 19, 626-36.

Dutta-Bergman, M. J., and W. D. Wells (2002), "The Values and Lifestyles of Idiocentrics and Allocentrics in an Individualist Culture: A Descriptive Approach," Journal of Consumer Psychology, 12(3), 231-242.

Fang, Eric, Robert W. Palmatier, and Kenneth R. Evans (2004), “Goal-Setting Paradoxes? Trade-Offs between Working Hard and Working Smart: The United States versus China," Journal of the Academy of Marketing Science, 32(2), 188-202.

Follows, Scott B. and David Jobber (2000), "Environmentally Responsible Purchase Behavior: A Test of A Consumer Model," European Journal of Marketing, 34(5/6), 723-46.

Fowler, Geoffrey A (2002), "Green Sales Pitch Isn't Moving Many Products," Wall Street Journal, March 6, B1-B4. 
Furnham, Adrian (1984), “The Protestant Work Ethic: A Review of the Psychological Literature," European Journal of Social Psychology, 14, 87-104. Goldman, Debra (1991), "Shoppers Still Don't See Green," Adweek, Feburary 4, 12. Goldsmith, Ronald E., Barbara A. Lafferty, and Stephen J. Newell (2000), “The Impact of Corporate Credibility and Celebrity Credibility on Consumer Reaction to Advertisements and Brands," Journal of Advertising, 29(3), 43-54.

Goldstein, Jerome (1996), "Furniture, Fashion and Food at Bio Fach," In Business, 18(3), 6. Government Information Agency (2003), "A Report on the Study Commissioned by Korean Government Information Agency and the Ministry of the Environment," Opinion Survey on Air Pollution.

Granzin, Kent L. and Janeen E. Olsen (1991), "Characterizing Participants in Activities Protecting the Environment: A Focus on Donating, Recycling, and Conservation Behaviors," Journal of Public Policy \& Marketing, 10 (2), 1-27.

Grunert, Klaus G., Suzanne C. Grunert, and Sharon E. Beatty (1989), "Cross-cultural Research on Consumer Values," Marketing and Research Today, February, 30-9.

Grunert-Beckmann, Suzanne C. and William E. Kilbourne (1997), "The Dominant Social Paradigm Value Systems, and Environmental Concern: Examining the Human Triad's (in)compatibilities," in Falkenberg A. and Rittenburg T. L. (Eds.), $22^{\text {nd }}$ Macromarketing Conference Proceedings, Bergen, Norway, Linooln, Nebraska: Macromarketing Association, University of Nebraska, 122-8. Guagnano, Gregory A., Paul C. Stern, and Thomas. Dietz (1995), "Influences on AttitudeBehavior Relationships: A Natural Experiment with Curbside Recycling," Environmental and Behavior, 27, 699-718.

Hastak, Manoj, Romana L. Horst, and Michael B. Mazis (1994), "Consumer Perceptions about and Comprehension of Environmental Terms: Evidence from Survey Research Studies," in Proceedings of the 1994 Marketing and Public Policy Conference, D. J. Ringold, ed., Washington, DC: University of Baltimore, 94-108.

Hines, Jody M., Herald R. Hungerford, and Audrey N. Tomera (1987), “Analysis and Synthesis of Research on Responsible Environmental Behavior: A Meta-Analysis," Journal of Environmental Education, 18, 1-8. Hofstede, Geert H. (1980), Culture's Consequences. Sage, Thousand Oaks.

Hofstede, Geert H. (1991), Cultures and Organizations: Software of the Mind. McGraw-Hill, New York.

Hopper, Joseph R., and Joyce McCarl Nielsen (1991), "Recycling as Altruistic Behavior: Normative and Behavioral Strategies to Expand Participation in A Community Recycling Program," Environment and 
Behavior, 23, 195-220.

Hui, C. Harry and Harry C. Triandis (1985), "Measurement in Cross-Cultural Psychology: A Review and Comparison of Strategies," Journal of Cross-Cultural Psychology, 16, 131-52.

Irvine, Sid H. and William K. Carroll (1980), "Testing and Assessment across Cultures: Issues in Methodology and Theory," in Triandis, H.C. and Berry, J.W. (Eds.), The Handbook of Cross-Cultural Psychology, Vol. 2, Allyn \& Bacon, Boston, 127-80.

Joreskog, Karl G. and Dag Sorbom, LISREL: Analysis of Linear Structural Relationships by Method of Maximum Likelihood User's Guide, $2^{\text {nd }}$ ed. National Educational Resources, Chicago, 1993.

Karp, David G. (1996), "Values and Their Effect on Pro-environmental Behavior," Environment and Behavior, 28, 111-133.

Kellgren, Carl A. and W. Wood (1986). “Access to Attitude-Relevant Information in Memory as A Determinant of AttitudeBehavior Consistency," Journal of Experimental Social Psychology, 22, 328-38.

Kelly, B. (1993), "The New Consumer Revealed,"

Sales and Marketing Management, 145, 46-52.

Kerr, Kevin (1990), “Thinking Green Is No Longer A Hippie Dream," Ad Week Marketing Week, 31, 18-19.

Kilbourne, William, P. McDonagh, and A. Prothero (1997), “Sustainable Consumption and the Quality of Life: A Macromarketing Challenge to the Dominant Social Paradigm," Journal of Macromarketing, 17, 4-24.

Kinnear, Thomas C. and James R. Taylor (1973), "The Effect of Ecological Concern on Brand Perceptions," Journal of Marketing Research, 10, 191-7.

Klein, Easy (1990), "The Selling of Green," D\&B Reports, 38 (September/October). 30-1.

Kohl, Helen (1990), “Earthly Goods," Canadian Consumer Magazine, 20 (7\&8), 9-22.

Lawrence, Jennifer (1993), "Green Product Sprouting Again: More Focused Efforts Avoid Controversy," Advertising Age, May 10, 12.

Lee, Chol (1990), "Modifying an American Consumer Behavior Model for Consumers in Confucian Culture: The Case of Fishbein Behavioral Intentions Model," Journal of International Consumer Marketing, 3, 2750.

Levin, Gary (1990), "Consumers Turning Green: JWT survey," Advertising Age, 61(47), 74.

Lynch, Barbara D. (1993), “The Garden and the Sea: U.S. Latino Environmental Discourses and Mainstream Environmentalism," Social Problems, 40, 108-24.

Mainieri, Tina, Elaine G. Barnett, Trisha R. Valdero, John B. Unipan, and Stuart Oskamp (1997), "Green buying: The Influence of 
Environmental Concern on Consumer Behavior," The Journal of Social Psychology, 137, 189-204.

Maio, Gregory R. and James M. Olson (1995), "Relations between Values, Attitudes, and Behavioral Intentions: The Moderating Role of Attitude Function," Journal of Experimental Social Psychology, 31, 266285.

Marketing News (1997), "Marketing Briefs," 31 (June 9), 2.

Mayer, Robert N., Debra L. Scammon, and Cathleen D. Zick (1993), "Turning the Competition Green: The Regulation of Environmental Claims," Proceedings of the 1992 Marketing and Public Policy Conference, Chapel Hill, NC, 152-65.

McCarty, John A. and L. J. Shrum (1994), "The Recycling of Solid Wastes: Personal and Cultural Values and Attitudes about Recycling as Antecedents of Recycling Behavior," Journal of Business Research, 30, 53-62.

McCarty, John A. and L. J. Shrum (2001). "The Influence of Individualism, Collectivism, and Locus of Control on Environmental Beliefs and Behavior," Journal of Public Policy \& Marketing, 20, 93-104.

McKenzie-Mohr, Doug, Lisa S. Nemiroff, Laurie Beers, and Serge Desmarais (1995), "Determinants of Responsible Environmental Behavior," Journal of Social Issues, 51, 139-56.
Morris, Louis A., Manoji Hastak, and Michael S. Mazis (1995), "Consumer Comprehension of Environmental Advertising and Labeling Claims," Journal of Consumer Affairs, 29, 328-350.

Neuman, Keith (1986), "Personal Values and Commitment to Energy Conservation," Environment and Behavior, 18, 53-74.

Noe, Francis P. and Rob Snow (1989-1990), "Hispanic Cultural Influence on Environmental Concern," Journal of Environmental Education, 21(2), 27-34.

Olson, James M. and Mark P. Zanna (1993), “Attitudes and Attitude Change," Annual Review of Psychology, 44, 117-54.

Ottman, Jacquelyn (1993), “Industry's Response to Green Consumerism," Journal of Business Strategy, 13, 3-7.

Ottman, Jacquelyn (1998), Green Marketing $2^{\text {nd }}$ ed., Lincolnwood, IL: NTC Business Books.

Park, H. and J. Kim (2003), "The Recognition of Corporate Environment-Friendly Activity on the Basis of the Degree of Involvement in Environment," The Korean Journal of Advertising, 14(3), 65-86.

Parker, Julia Dawn and Maureen H. McDonough (1999), "Environmentalism of African Americans," Environment and Behavior. 31(2), 155-77.

Parsons, Talcott and Edward A. Shils (1951), Toward a General Theory of Action, Cambridge: Harvard University Press. 
Rankin, William L. (1983), “The Influence of Human Values on Conservation and Energy Shortage Beliefs," in Conn, W.D. (Ed.), Energy and Material Resources: Attitudes, Values, and Public Policy. Westview Press, Boulder.

Roberts, James A. (1996), "Green Consumers in the 1990s: Profile and Implications for Advertising," Journal of Business Research, 36, 217-31.

Rozak, Theodore (1992), The Voice of the Earth. New York, Simon and Schuster.

Schlossberg, Howard (1992), "Kids Teach Parents How to Change Their Buying Habits," Marketing News, 26, 8.

Schultz, P. Wesley and Lynnette C. Zelezny (1998), "Values and Proenvironmental Behavior:

A Five-country Survey," Journal of CrossCultural Psychology, 29, 540-558.

Schultz, P. Wesley and Lynnette C. Zelezny (1999), "Values as Predictors of Environmental Attitudes: Evidence for Consistency across 14 Countries," Journal of Environmental Psychology, 19, 255-65.

Schwartz, Shalom H. (1992), "Universals in the Content and Structure of Values: Theoretical Advanoes and Empirical Tests in 20 Countries," Advances in Experimental Social Psychology, 25, 1-65.

Schwartz, Shalom H. (1994), "Are There Universal Aspects in the Structure and Contents of Human Values?" Journal of Social Issues, 50 (4), 19-45.
Schwartz. Shalom H. and T. Miller (1991), "The Earth's Best Friends," American Demographics, 26(February), 35. Selling (2002), "Sales Trends," June, 2. Seoul City (1997), "Survey on Citizenship about Environmental Problems," A Report by the Seoul City.

Shrum, L. J., John A. McCarty, and Tina M. Lowrey (1995), "Buyer Characteristics of the Green Consumer and Their Implications for Advertising Strategy," Journal of Advertising, 24, 71-82.

Simmons, Deborah and Ron Widmar (1990), "Motivations and Barriers to Recycling: Toward a Strategy for Public Education," The Journal of Environmental Education, 22, 13-18.

Steenkamp, Jan-Benedict E.M. and Hans Baumgartner (1998), “Assessing Measurement Invariance in Cross-national Consumer Research," Journal of Consumer Research, 25, 78-90.

Stern, Paul C. and Thomas Dietz (1994), "The Value Basis of Environmental Concern," Journal of Social Issues, 50, 65-84.

Stern, Paul C., Thomas Dietz, and Linda Kalof (1993), "Values Orientations, Gender, and Environmental Concern," Environment and Behavior, 25, 322-48.

Stern, Paul C., Thomas Dietz, Linda Kalof, and Gregory A. Guagnano (1995), "Values, Beliefs, and Proenvironmental Action: Attitude Formation toward Emergent Attitude Objects," 
Journal of Applied Social Psychology, 25, 1611-36.

Triandis, Harry C. (1990), "Cross-cultural Studies of Individualism and Collectivism," in Berman, J. (Ed), Nebraska Symposium on Motivation, University of Nebraska Press, Lincoln, 41-133.

Triandis, Harry C., C. McCusker, and C. Harry Hui (1990), "Multimethod Probes of Individualism and Collectivism," Journal of Personality and Social Psychology, 59, 100620.
Wayne, F. Stanford (1989), “An Instrument to Measure Adherence to the Protestant Ethic and Contemporary Work Values," Journal of Business Ethics, 8, 793-804.

William, Atkinson (2000), "Buyer Demand for Green Office Products Blossoms," Purchasing, 129(1), 211-213.

Williams, R.M., Jr. (1979), “Change and Stability in Values and Value Perspectives: A Sociological Perspectives," in Rokeach, M. (Ed.), Understanding Human Values: Individual and Societal, Free Press, New York. 


\section{가치구조와 환경소비주의에 관한 타 문화간 비교연구: 한국과 미국 소비자사례}

김 연 신* 최 세 정** 노라 리폰***

\section{국문요약}

친환경구매행위에 대한 이해를 도모하고 소비자에게서 나타나는 환경의식과 실제 행위간의 차이를 좁히기 위한 노력으로, 본 논문은 소비자들의 차별적 환경태도 및 행위의 원인을 소비자의 가치구조 와 연결시켰다. 이를 위해 본 연구에서는 소비자가치구조와 친환경소비주의간의 관계를 설명하는 포 괄적 연구모형을 제안하고 한국과 미국의 소비자를 대상으로 실증 분석하였다. 두 나라는 문화적 측 면에서 이질적이며, 따라서 소비자들의 친환경성향과 관계 있는 가치체계도 다를 것이다. 연구를 위 한 자료는 각 나라에 거주하는 대학생 소비자들을 대상으로 실시한 설문조사를 통해 수집되었으며 구조방정식모형을 이용하여 각 나라별 그리고 다중 집단 수준(multi-group level)에서 분석하였다. 분석결과, 특정 가치체계와 환경태도 및 친환경구매행위의 중요한 관련성이 발견되어진 반면, 구체적 으로 고려된 세 가지 가치체계, 태도, 행위의 관계유형들이 두 나라 사이에 차이가 있는 것으로 나타 났다. 즉, 소비자의 가치체계가 그들의 친환경태도 및 소비행위에 중요한 영향을 미치지만 어떤 가치 체계가 어떻게 구매행위에 영향을 미치는지는 그 나라의 문화적 특성에 따라 다를 수 있음을 발견하 였다. 본 연구의 결과는 글로벌 친환경마케팅을 시도하는 국제 마케터들에게 중요한 시사점을 제공 한다.

핵심개념: 가치구조, 환경태도, 친환경구매행위, 비교문화연구

\footnotetext{
* 명지대학교 경영학과 조교수

** 텍사스주립대학교 광고학과 부교수

*** 미시간주립대학교 광고학과 교수
} 